\title{
The Role of Zakat Potential in Reducing Poverty in Turkey Niyazi Gümüş ${ }^{*}$ Fatih Yardımcıoğlu* Nurullah Altıntaşs**
}

Received: 11.06 .2019

Accepted: 27.07.2019

DOI: $10.25272 /$ ijisef.575488

Type: Research Article

\begin{abstract}
Poverty has been the leading social and economic problem of societies both in the past and today for the decades. This study examines the status of poverty in the Turkish economy and the role of zakat in poverty reduction. The zakat potential is analyzed in three methods and it is concluded that poverty in Turkey could be completely resolved via a potential zakat fund. It is suggested that to reduce poverty in Turkey, zakat should be enforced by favor of the state and it should be based on institutional foundations.
\end{abstract}

Keywords: Poverty, Reduction Poverty, Zakat, Zakat Potential

Jel Codes: E62, I31, P24, Z12.

\footnotetext{
* PhD Student, Sakarya University, Institute of Social Sciences, E-mail:gumusniyazi@hotmail.com; This study is derived from the doctoral dissertation titled "A solution to poverty reduction: an example of a zakat fund", ORCID: https://orcid.org/0000-0002-3928-6937

${ }^{* *}$ Assoc. Professor, Sakarya University, Faculty of Political Sciences, Department of Public Finance, Email: fyoglu@sakarya.edu.tr, ORCID: https://orcid.org/0000-0002-7758-8549

${ }^{* * *}$ Assistant Professor, Sakarya University, Faculty of Political Sciences, Department of Economics, Email: naltintas@sakarya.edu.tr, ORCID: https://orcid.org/0000-0001-9425-3516
} 


\section{Introduction}

Poverty has been the leading fundamental problem since the beginning of the history of humanity, and even today, societies try to overcome it. Human beings need to fulfill their basic needs such as water, food and shelter. Some people in the world can fulfill these needs, while some cannot. The people who have difficulty in maintaining their lives are described as poor by the society (Bozan, 2010: 36). Poverty was first defined in 1901 by Seebohm Roventree. According to Roventree's definition, poverty is the condition in which a person's total income is not sufficient to fulfill his/her minimum physiological needs, such as food and clothing that are required to maintain his/her biological existence (Arpacıoğlu and Yıldırım, 2011: 60).

In reference to another definition, poverty is the condition in which people do not have the means to fulfill their basic needs such as food, shelter and clothing, and in which people maintain their lives under minimum living standards (Öztürk and Çetin: 2664; Gül and Ergun, 2003: 389).

According to Islam, poverty is the condition in which a person's property does not amount to nisab. The people that do not possess property or money amounting to nisab (equivalent to 80 grams of gold), even though they have fulfilled their basic needs such as a house, household goods and a mount, are considered poor according to Islam. The ones who possess nothing and have to beg for food are called miskeen (Bilmen, ty: 358). In the Islamic literature, being miskeen can be defined as extreme poverty.

When we refer to the ayats and hadiths, we see that helping poor people and fulfilling their needs are duties for the wealthy. It has been stated that people cannot be indifferent to one another in an Islamic society. With reference to this understanding in Islam, the poor and needy have been taken care of, and waives and orphans have been helped in Islamic societies.

Although there are various means to reduce poverty, we come across zakat as the most significant means in Islam. The zakat system provides wealth by receiving from the rich Muslims and donating to the poor.

This study examines the rate and amount of poverty in Turkey. It analyzes in three methods the zakat potential in the Turkish economy and discusses the sufficiency of zakat as an alternative solution to reduce poverty.

\section{A Conceptual Look at Poverty and Zakat}

While there are different definitions of poverty in literature, the most referenced terms are absolute poverty, relative poverty and humanitarian poverty.

Absolute poverty is the condition in which people cannot obtain the materials for the minimum basic needs required (Bozan, 2010: 38). It is the condition in which the minimum physical needs to survive cannot be fulfilled. The ones in the absolute poverty condition cannot even fulfill their basic humanitarian needs, and in case there is no external help, they face death risks. As designated by the World Health Organization (WHO), poverty is the condition in 
which an adult gets less than $2100 \mathrm{kcal}$ daily, and it is admitted that the ones who get less than this amount are living under the hunger threshold. Even though there is absolute poverty worldwide, it is mostly seen in the least developed countries and developing countries (Taş and Özcan, 2012: 424).

Prices are important in determining the absolute poverty thresholds of countries. The price differences in countries cause differences in poverty lines, as well. The absolute poverty threshold for the Eastern European countries, including Turkey, has been determined as $4 \$$ per day (Tireli, 2009: 33).

Relative poverty is a term related to income distribution. While this term is used in all countries, it is mostly seen in the developed and developing countries (Tatll, 2013: 10). Relative poverty is the condition in which the income level of an individual is below a specific rate of the social wealth level. This rate is generally accepted as $50 \%$. The OECD countries have designated the average wealth level as $50 \%$ to determine the poverty line in poverty comparisons. Accordingly, when the incomes of individuals are ordered from the lowest to the highest, the one in the middle is accepted as the poverty line. The ones whose total income is below this line are accepted as relatively poor (TÜSİAD, 2000: 98; Gönel, 2010: 33). The relative poverty rate is the ratio of the ones, whose per capita consumption is below the poverty line based on the individual median income, to the total population (Ensari, 2010: 10).

Humanitarian poverty term was first introduced in 1997 in the Human Development Report by United Nations Development Program (UNDP). It is a poverty criterion developed by UNDP, and it is the condition in which individuals do not have the means to live humanly (Aktan, 2002: 1). As income poverty measurements focus on absolute poverty, humanitarian poverty focuses on the lack of basic humanitarian qualities such as illiteracy, malnutrition, short life span, inadequate maternal-child health care and getting preventable diseases (Taş and Özcan, 2012: 425).

In the Islamic point of view, the poverty term is categorized in two types as poor and miskeen. Islam designates as poor the ones that do not possess any property amounting to nisab, despite fulfilling their basic needs such as food, clothing and shelter, and not facing the risk of starvation. This is measured as the equivalent to 80.18 grams of gold, and the ones whose wealth, except the fundamental needs such as a house, a car and clothing, is below this amount are considered poor. Miskeen, on the other hand, is described as the person that do not possess anything and has to beg to fulfill his/her basic needs such as food and clothing (Akar and Eser, 2012: 77; Erkal, 2007: 477).

In the dictionary, which means cleaning up, multiplying blessing and growing zakat (Yavuz, 2018: 31), is donating to the needy Muslims for Allah's sake a portion of the property amounting to nisab, defined in accordance with the ayats and sunnah (hadiths), at a specific time (Yildırım, 1980:107). Pursuant to Islam, zakat is the donation by the wealthy Muslims, of gold, money, agricultural products, livestock, minerals, industrial products and commercial products in the amounts and to the recipients defined in the Qur'an and sunnah. Zakat is a 
financial worship as well as being fard, and it can be seen that it has a significant role in poverty reduction, when used in the Islamic standards. This fact is confirmed by the enforcements in different periods in the history of Islam.

\section{The Role of Zakat in Poverty Reduction}

It is reported that zakat enforcement goes back to the Prophet (pbuh)'s prophethood in Mecca. In this period, zakat was not imperative, but it was encouraged and recommended. It was encouraged to help the poor and needy Muslims. Referring to the 4th ayat of Surah AlMu'minun: "And they who are observant of zakat". Some scholars report that zakat was made fard in Mecca. However, as the Muslims did not have a state in Mecca, it was neither imperative to give zakat nor zakat was collected by the state (Dumlu, 2010: 99).

In another view, on the other hand, it is indicated that zakat was made fard in the second year of hijrah, and that Muslims were handing in their zakat to the Prophet (pbuh) by the ninth year of hijrah. In the ninth year of hijrah $103^{\text {rd }}$ ayat of Surah At-Tawbah descended, and it is noted that zakat was collected and distributed to the poor by the state, along with the order: "Take alms out of their property" (Kılıç, 2017: 48-50; Samad and Glenn, 2010: 307). The Prophet (pbuh) assigned zakat officials to collect and distribute zakat. He notified the officials via letters about the rules indicating how and what amount of zakat is to be taken from specific properties, and demanded that the officials act accordingly (Kılıç, 2017: 51-57). The officials collected the zakat in the manner determined by the Prophet (pbuh) and distributed them to the poor in the region (Yavuz, 1972: 309).

During the period of the Rashidun Caliphs, as well, after the Prophet (pbuh) had passed away, the Caliphs followed the Prophet (pbuh)'s way. They acted in accordance with the documents that He dictated (Bilmen, t.y: 340-352).

During the Caliph Omar's period the zakat revenues increased. Muaz b. Jabal, who had been sent to Yemen by the Prophet (pbuh) as the governor, remained in office during Caliph Omar's era and sent the $1 / 3$ of the zakat revenues to Medina. When Caliph Omar reminded that zakat should be collected from the wealthy in the region and distributed to the poor, Muaz b. Jabal stated that he had distributed zakat to the poor in the region and that he had sent the surplus. In the second year, he sent half of the zakat collected. Caliph Omar once again reminded that zakat should be collected from the wealthy in Yemen and distributed to the poor. Muaz b. Jabal, on the other hand, stated that he had distributed zakat to the poor and that he had sent the surplus. And in the third year, he sent to Medina the total zakat revenues collected, and informed that there was no one in Yemen to give zakat. This shows that during the Caliph Omar's period, the poverty problem was resolved in some regions by means of zakat (Boynukalın, 2017: 97-98; Rizvi, 1981: 18; Kutup, 1968: 442). It became harder to find a poor person to give zakat during the Caliph Omar's period. He adopted the principle of giving zakat until the poor turned rich. He ordered that the total zakat collected be distributed (Saad and Sawandi, 2016: 173). In this period, a council board was established to record the public revenues. 
Following Caliph Uthman's martyrdom, Muslims hesitated about whom to give zakat. Sa'ad bin Abu Vakkas, Abu Hurairah and some other companions of the Prophet (pbuh) stated that zakat was to be given to the sultan. Abdullah ibn Omar, too, stated that zakat was to be given to the rulers (Apak, 2017: 165).

During the Umayyad and Abbasid periods, the council board improved, and "Diwan AlSadaqah" (Council for Alms) was established. Caliph Omar ibn Abdul Aziz also adopted the principle of distributing zakat where it is collected. He ordered the officials that zakat be distributed where it is collected, and that it be transferred to and distributed in the closest region, in case of a surplus (Apak, 2017: 312). In the Caliph Omar ibn Abdul Aziz's era, it got harder to find poor people to give zakat (Er, 2016: 65). Thus, the Caliph freed the slaves with the zakat revenues by taking judicial decisions regarding zakat. Houses were built and given to the poor for free, the young who wanted to get married were helped, and mounts were donated to the ones without a means of transport (Saad and Sawandi, 2016: 442). This shows that zakat is one of the most effective means of poverty reduction, if the zakat revenues are collected and spent properly by the government.

Imam Abu Yusuf, who was appointed as the head kadi in the Abbasid era, followed the Prophet (pbuh)'s way, adopting the opinion that zakat should be distributed where it is collected, and that it would not be proper to transfer it to somewhere else before distributing it to the poor in the region (Yeşilyurt, 2015: 108). Kardavi also believes that the distribution of zakat in the region where it is collected would not be transferred to other regions unless there is valid reason (Kardavi, 2017: 51).

\section{Current Poverty and Zakat Potential in Turkey}

Poverty in Turkey is not peculiar to today, but it is a condition dating back to the first years of the Republic. Even though Turkey did not participate in the Second World War, it was subjected to the negative effects of the war and poverty persisted, along with the destruction by the Turkish war of independence (Kayalıdere and Şahin, 2014: 68; Kızıler, 2017: 85).

Poverty in Turkey was brought to the agenda in the 1950s. As industrialization expanded in the 1950s, migration from rural to urban areas began. And the migration from rural to urban areas caused urban squatting and an increase in the infrastructure problems. The migrants had to live in urban slums, due to lack of economic opportunities. In these places, the former comers tried to help the later comers. At that time, poverty was not so evident, thanks to the traditional institutions and moral values. However, since the 1980s, poverty has become apparent (Açıkgöz and Yusufoğlu, 2012: 82). And since the second half of the 1980s, during the ANAP government led by Turgut Özal, the poverty problem has begun to be dealt with (Gül, 2002: 112).

The economy downsized, unemployment increased and income distribution deteriorated, due to the economic crises in Turkey in the 1990s. Despite the economic growth, increased unemployment caused increased poverty. The economic crisis in 1994, specifically, led the poverty to be more evident. The inequality in income distribution increased more and more 
in Turkey, where economic crises continued in the 2000s. 2 million people in Turkey became unemployed by the economic crisis in 2001. Although Turkey was little affected by the global crisis of 2010 and 2011, the crises increased the inequality in income distribution (Yildirımalp, 2017: 248-249). Turkey ranked among one of the countries where the inequality in income distribution is the highest in the world. The fact that the inequality in income distribution increased because of crises led the gap between the top and bottom income groups to widen gradually, and the income distribution to deteriorate further (Arabac1, 2014: 184).

\subsection{Current Poverty Indicators in Turkey}

Based on the table 1, food poverty (hunger) rate in Turkey is quite low. This rate was $1.35 \%$ in 2002 and decreased to $0.48 \%$ in 2009 . The hunger rate in urban areas was $0.92 \%$ in 2009 and decreased to $0.06 \%$ in 2009 . In rural areas, it decreased from $2.01 \%$ in the same period to $1.42 \%$ in 2009. The hunger rate in rural areas in 2009 is 23 -fold of that in urban areas. While the number of people living under the hunger threshold in Turkey was 926 thousand in 2002, it decreased to 539 thousand in 2006. In the same period, the number of people suffering from hunger in urban areas decreased from 376 thousand to 18 thousand, as the number of people suffering from hunger in rural areas decreased from 550 thousand to 521 thousand. The number of people living under the hunger threshold in urban areas reduced 21-fold, while the reduction rate in the ones in rural areas was only 5\% (Kabaş, 2010: 195).

World Bank designated 4.3\$ per capita daily as the poverty line for Eastern Europe and Turkey. Accordingly, poverty rate in Turkey was 30.3\% in 2002, and this rate decreased to $20.89 \%$ in 2004 ; to $13.33 \%$ in 2006; to $6.83 \%$ in 2008; and to $4.35 \%$ in 2009 (TurkStat: 2015; Çilingiroğlu, 2009: 27). The rate of those with an income below $4.3 \$$ daily reduced to $3.66 \%$ in 2010; to $2.27 \%$ in 2012 ; to $2.06 \%$ in 2013 ; to $1.62 \%$ in 2014 ; and to $1.58 \%$ in 2015 . Turkey's population was 78,741 thousand in 2015 , and the number of those with an income below $4.3 \$$ daily was 1,244 thousand. In 2002, the rate of those living under the poverty line of $4.3 \$$ daily was $24.62 \%$ in urban areas, while this rate decreased to $0.96 \%$ in 2009 ; to $0.94 \%$ in 2011 ; and to $0.64 \%$ in 2013. On the other hand, in rural areas in 2002, this rate was $38.82 \%$, and it reduced to $11.92 \%$ in 2009 ; to $6.83 \%$ in 2011; and to $5.13 \%$ in 2013 (TurkStat, 2015). While poverty reduced 38 -fold in urban areas, it reduced 7 -fold in rural areas.

In Turkey, the poverty rate based on food + non-food expenditure was $26.96 \%$ in 2002 , it reduced to $20.50 \%$ in 2005 ; and to $18.08 \%$ in 2009 . In the same period, this rate decreased from $21.95 \%$ to $8.86 \%$ in urban areas, while it increased from $34.48 \%$ to $38.69 \%$ in rural areas. The poverty rate based on food + non-food expenditure decreased in urban areas, as it increased in rural areas. The number of poor people based on food + non-food expenditure was 18,441 thousand in 2002, decreased to 12,930 thousand in 2006, but it increased to 13,119 thousand in 2009. In the 2002-2006 period, as the number of poverty based on food + non-food expenditure decreased from 9,011 thousand to 4,225 thousand in urban areas, it decreased from 9,429 thousand to 8,706 thousand in rural areas. In this period, there was a reduction of 5.5 million in the number of poor people, while 4.8 million of this amount was in urban areas and 0.7 
million was in rural areas. Turkey's population increased by 3,3 million in this period, as the number of poor people reduced by 5.3 million (TurkStat, 2015; Kabaş, 2010: 197).

In Turkey, while the rate of relative poverty based on expenditure was $14.74 \%$ in 2002 , it increased to $15.15 \%$ in 2009 with a rising and falling course. In the same period, the rate of relative poverty based on expenditure decreased from $11.33 \%$ to $6.59 \%$ in urban areas, and it increased from $19.86 \%$ to $34.20 \%$ in rural areas (TurkStat, 2015). In the interim period, as the rate of relative poverty based on expenditure decreased by $42 \%$ in urban areas, it increased by $72 \%$ in rural areas. This shows that poverty in rural areas increased significantly in the interim period (Çalışkan, 2010: 120).

Because most of the poor in Turkey are living on a level close to the food poverty threshold, it is possible to save them from poverty with a small transfer aid. However, the efficiency of the transfer expenditure aimed at the poor in Turkey has not yet reached to the desired level (DPT, 2010: 15-16).

Table 1: The Poverty Rates of Individuals According to Poverty Line Methods (Turkey), 2002$2009(\%)$

\begin{tabular}{|l|l|l|l|l|l|l|l|l|}
\hline Years & $\mathbf{2 0 0 2}$ & $\mathbf{2 0 0 3}$ & $\mathbf{2 0 0 4}$ & $\mathbf{2 0 0 5}$ & $\mathbf{2 0 0 6}$ & $\mathbf{2 0 0 7}$ & $\mathbf{2 0 0 8}$ & $\mathbf{2 0 0 9}$ \\
\hline $\begin{array}{l}\text { Food Poverty } \\
\text { (hunger) }\end{array}$ & 1.35 & 1.29 & 1.29 & 0.87 & 0.74 & 0.48 & 0.54 & 0.48 \\
\hline $\begin{array}{l}\text { Complete Poverty } \\
\text { (food+non-food) }\end{array}$ & 26.96 & 28.12 & 25.60 & 20.50 & 17.81 & 17.79 & 17.11 & 18.08 \\
\hline $\begin{array}{l}\text { Below 2.15 \$ per } \\
\text { capita per day }\end{array}$ & 3.04 & 2.39 & 2.49 & 1.55 & 1.41 & 0.52 & 0.47 & 0.22 \\
\hline $\begin{array}{l}\text { Below 4.3 \$ per } \\
\text { capita per day }\end{array}$ & 30.30 & 23.75 & 20.89 & 16.36 & 13.33 & 8.41 & 6.83 & 4.35 \\
\hline $\begin{array}{l}\text { Relative poverty } \\
\text { based on expenditure }\end{array}$ & 14.74 & 15.51 & 14.18 & 16.16 & 14.50 & 14.70 & 15.06 & 15.15 \\
\hline Urban & 0.92 & 0.74 & 0.62 & 0.64 & 0.04 & 0.07 & 0.25 & 0.06 \\
\hline $\begin{array}{l}\text { Food Poverty } \\
\text { (hunger) }\end{array}$ & 21.95 & 22.30 & 16.57 & 12.83 & 9.31 & 10.36 & 9.38 & 8.86 \\
\hline $\begin{array}{l}\text { Complete Poverty } \\
\text { (food+non-food) }\end{array}$ & 2.37 & 1.54 & 1.23 & 0.97 & 0.24 & 0.09 & 0.19 & 0.04 \\
\hline $\begin{array}{l}\text { Below 2.15 \$ per } \\
\text { capita per day }\end{array}$ & 24.62 & 18.31 & 13.51 & 10.05 & 6.13 & 4.40 & 3.07 & 0.96 \\
\hline $\begin{array}{l}\text { Below 4.3 \$ per } \\
\text { capita per day }\end{array}$ & 11.26 & 8.34 & 9.89 & 6.97 & 8.38 & 8.01 & 6.59 \\
\hline $\begin{array}{l}\text { Relative poverty } \\
\text { based on expenditure }\end{array}$ & 11.33 & & & & & & & \\
\hline Rural
\end{tabular}




\begin{tabular}{|l|l|l|l|l|l|l|l|l|}
\hline $\begin{array}{l}\text { Food Poverty } \\
\text { (hunger) }\end{array}$ & 2.01 & 2.15 & 2.36 & 1.24 & 1.91 & 1.41 & 1.18 & 1.42 \\
\hline $\begin{array}{l}\text { Complete Poverty } \\
\text { (food+non-food) }\end{array}$ & 34.48 & 37.13 & 39.97 & 32.95 & 31.98 & 34.80 & 34.62 & 38.69 \\
\hline $\begin{array}{l}\text { Below 2.15 \$ per } \\
\text { capita per day }\end{array}$ & 4.06 & 3.71 & 4.51 & 2.49 & 3.36 & 1.49 & 1.11 & 0.63 \\
\hline $\begin{array}{l}\text { Below 4.3 \$ per } \\
\text { capita per day }\end{array}$ & 38.82 & 32.18 & 32.62 & 26.59 & 25.35 & 17.59 & 15.33 & 11.92 \\
\hline $\begin{array}{l}\text { Relative poverty } \\
\text { based on expenditure }\end{array}$ & 19.86 & 22.08 & 23.48 & 26.35 & 27.06 & 29.16 & 31 & 34.20 \\
\hline
\end{tabular}

Source: TurkStat, Poverty Study, 2015.

Table 2: The Poverty Rates of Individuals According to Poverty Line Methods (Turkey), 20102015 (\%)

\begin{tabular}{|l|l|l|l|l|l|l|}
\hline & $\mathbf{2 0 1 0}$ & $\mathbf{2 0 1 1}$ & $\mathbf{2 0 1 2}$ & $\mathbf{2 0 1 3}$ & $\mathbf{2 0 1 4}$ & $\mathbf{2 0 1 5}$ \\
\hline $\begin{array}{l}\text { Those who live below 2.15 \$ } \\
\text { per capita per day }\end{array}$ & 0.21 & 0.14 & 0.06 & 0.06 & 0.03 & 0.06 \\
\hline $\begin{array}{l}\text { Those who live below 4.3 \$ } \\
\text { per capita per day }\end{array}$ & 3.66 & 2.79 & 2.27 & 2.06 & 1.62 & 1.58 \\
\hline Urban & & & & & & \\
\hline $\begin{array}{l}\text { Those who live below 2.15 \$ } \\
\text { per capita per day }\end{array}$ & 0.04 & 0.02 & 0.02 & 0.02 & - & - \\
\hline $\begin{array}{l}\text { Those who live below } 4.3 \$ \\
\text { per capita per day }\end{array}$ & 0.97 & 0.94 & 0.60 & 0.64 & & \\
\hline $\begin{array}{l}\text { Rural } \\
\text { Those who live below 2.15 \$ } \\
\text { per capita per day }\end{array}$ & 0.57 & 0.42 & 0.14 & 0.13 & - & - \\
\hline $\begin{array}{l}\text { Those who live below } 4.3 \$ \\
\text { per capita per day }\end{array}$ & 9.61 & 6.83 & 5.88 & 5.13 & - & - \\
\hline
\end{tabular}

Source: TurkStat, Poverty Study, 2015. 
Table 3: Poverty in Turkey, Based on Median Equivalised Household Disposable Income, 2006-2007

\begin{tabular}{|l|l|l|l|l|l|l|l|l|}
\hline Years & $\mathbf{2 0 0 6}$ & $\mathbf{2 0 0 8}$ & $\mathbf{2 0 1 0}$ & $\mathbf{2 0 1 2}$ & $\mathbf{2 0 1 4}$ & $\mathbf{2 0 1 5}$ & $\mathbf{2 0 1 6}$ & $\mathbf{2 0 1 7}$ \\
\hline $50 \%$ & 2351 & 3164 & 3714 & 4515 & 5554 & 6246 & 7116 & 7944 \\
\hline $\begin{array}{l}\text { Poverty } \\
\text { Threshold TRY }\end{array}$ & 12,548 & 11,580 & 12,025 & 11,998 & 11,332 & 11,219 & 11,026 & 10,622 \\
\hline $\begin{array}{l}\text { Number of the } \\
\text { Poor } \\
\text { (Thousand) }\end{array}$ & 18.6 & 16.7 & 16.9 & 16.3 & 15 & 14.7 & 14.3 & 13.5 \\
\hline Poverty Rate \% & 31.7 & 25.6 & 26.6 & 26.9 & 24.4 & 25.3 & 24.3 & 22.6 \\
\hline Poverty Deficit & 2821 & 3797 & 4457 & 5418 & 6665 & 7495 & 8539 & 9532 \\
\hline $60 \%$ & 17,165 & 16,714 & 16,963 & 16,741 & 16,501 & 16,706 & 16,328 & 15,864 \\
\hline $\begin{array}{l}\text { Poverty } \\
\text { Threshold TRY }\end{array}$ & & & & & & & & \\
\hline $\begin{array}{l}\text { Number of the } \\
\text { Poor } \\
\text { (Thousand) }\end{array}$ & 25.4 & 24.1 & 23.8 & 22.7 & 21.8 & 21.9 & 21.2 & 20.1 \\
\hline Poverty Rate \% & 27.9 & 28.7 & 29.2 & 27.2 & 26.8 & 26.5 & 25.8 \\
\hline Poverty Deficit & 33.6 & 27.9 & & & & \\
\hline
\end{tabular}

Source: TurkStat, Income and Living Conditions Survey.

Median is the midpoint in a statistical range, dividing the range into two equal parts. Median income is the income of the individual in the middle of the sequence (Özdemir, 2017: 82).

In Table 3, poverty threshold in Turkish lira, poverty rates and number of the poor in Turkey between 2006 and 2017 are indicated, based on the individual median disposable income. According to the poverty threshold calculated based on the $60 \%$ of the individual median disposable income -also used by the EU member states- the poverty rate in Turkey was calculated $25.4 \%$ in $2006 ; 23.8 \%$ in $2010 ; 21.8 \%$ in $2014 ; 21.2 \%$ in 2016 ; and $20.1 \%$ in 2017 . In the interim period, the poverty rate decreased by 5.3 points. The number of the poor was 17,165 thousand in 2006, decreased to 15,864 thousand in 2017, and the number of the poor decreased by 1,301 thousand people (TurkStat, 2017).

According to the poverty calculation based on the $50 \%$ of the individual median disposable income, the poverty rate in Turkey was $18.6 \%$ in $2006 ; 16.9 \%$ in $2010 ; 14.7 \%$ in $2015 ; 14.3 \%$ in 2016; and $13.5 \%$ in 2017. In this period the poverty rate decreased by 5.1 points. Turkey's population was 69,729 thousand in 2006, it increased to 80,810 thousand in 2017 , and it increased by approximately 11 million in 12 years. The number of the poor based on the $50 \%$ of the individual median disposable income was 12,548 thousand in 2006; 10,622 thousand in 2017 , and the number of the poor decreased by 1,926 thousand. While the GDP per capita was 7,906 \$ in 2006, it increased to 10,602 \$ in 2017, increasing by 34\% (TurkStat, 2017). The fact that the GDP per capita in Turkey increased by $34 \%$ in dollar and that in the same period 
Turkey's population increased 11 million, while the number of the poor decreased by 1,9 million indicate that Turkish economy has developed.

Table 4: Income Distribution in Turkey, Based on 5 Percentiles

\begin{tabular}{|l|l|l|l|l|l|l|l|l|l|l|}
\hline $\begin{array}{c}\mathrm{i}^{\text {th }} \\
\text { percentile }\end{array}$ & 2006 & 2008 & 2010 & 2011 & 2012 & 2013 & 2014 & 2015 & 2016 & $\begin{array}{c}\text { 2016 Annual } \\
\text { Approximate } \\
\text { Per Capita } \\
\text { Income } \\
(\mathrm{TRY})\end{array}$ \\
\hline $1^{\text {st }}$ \% & 0.7 & 0.9 & 0.9 & 0.8 & 0.9 & 0.9 & 1 & 0.9 & 0.9 & 3,569 \\
\hline $2^{\text {nd }} \%$ & 1.1 & 1.3 & 1.3 & 1.3 & 1.3 & 1.4 & 1.4 & 1.4 & 1.4 & 5,465 \\
\hline $3^{\text {rd } \% 5}$ & 1.5 & 1.7 & 1.7 & 1.7 & 1.7 & 1.8 & 1.8 & 1.8 & 1.8 & 6,702 \\
\hline $4^{\text {th }} \% 5$ & 1.8 & 1.9 & 2 & 2 & 2 & 2 & 2.1 & 2.1 & 2 & 7,788 \\
\hline $5^{\text {th } \% 5}$ & 2.1 & 2.2 & 2.2 & 2.3 & 2.3 & 2.3 & 2.3 & 2.3 & 2.3 & 8,787 \\
\hline $6^{\text {th } \% 5}$ & 2.3 & 2.5 & 2.5 & 2.5 & 2.5 & 2.6 & 2.6 & 2.6 & 2.5 & 9,716 \\
\hline
\end{tabular}

Source: Çalışkan, 2010: 106; TurkStat, Statistics on Income Distribution and Living Conditions

In Table 4, the income distribution in Turkey along 2006-2016 is given in 5 percentiles. At the end of the table, the annual per capita income of each percentile is given. In 2016, the minimum wage was 1,300 TRY for the singles and 1,362 TRY for the married with two children (Republic of Turkey Ministry of Family and Social Policies, 2016).

The first 5 percentile's of GDP was $0.7 \%$ in 2006 and it increased to $0.9 \%$ in 2016. In 2016, the annual approximate per capita income of this group was 3,569 TRY and the monthly per capita income was 297 TRY. In 2016, minimum wage for the singles was 1,301 TRY; and 1,362 TRY for the married with one salary and two children. The monthly income of a family of four in this group is 1,190 TRY, even below the minimum wage. In 2016, the average exchange rate of dollar by the Central Bank was 3.022 TRY. The monthly income of a family of four in this group is $393.7 \$$, and the monthly per capita income is $98.4 \$$. The daily per capita income of this group is 3.28 \$. The poverty threshold designated for Turkey is $4.3 \$$. The daily poverty deficit of this group is $1.02 \$$. The table shows that this percentile is living under the poverty threshold.

In 2016, Turkey's population was 79,814,871. When the population is divided in 5 percentiles, the number of people per each percentile is $3,990,743$. The amount of transfer to save this group from poverty is $4,070,557 \$$ daily; $122,116,735 \$$ monthly; and $1,465,400,830 \$$ annually. This is 4.428.441.308 TRY.

The annual per capita income of the second 5 percentile was 5,465 TRY and the monthly per capita income was 455 TRY in 2016. The monthly approximate income of a family of four in this group was 1,821 TRY in 2016, and it was higher than the minimum wage. The monthly income of this group in 2016 was 602 \$; monthly per capita income was 150.6 \$; and daily per 
capita income was $5.02 \$$. This group has an income higher than the $4.3 \$$ of poverty threshold. Yet, this group lives with an income below the relative poverty threshold.

In the third 5 percentile, one person's income was 6,702 TRY annually; 558 TRY monthly; and 18.6 TRY; 6.16 \$ daily in 2016. The monthly approximate income of a family of four in this group is 2.234 TRY. The share this group received from the GDP was $1.5 \%$ in 2006 , while it increased to $1.8 \%$ in 2016 . There is 0.3 points of increase in the share this percentile received from the GDP.

Based on the $50 \%$ of the median income in Turkey, the poverty rate in 2016 was $14.3 \%$ (TurkStat). This shows that the first three 5 percentile are living under the relative poverty threshold.

The share the fourth 5 percentile received from the GDP was $1.8 \%$ in 2006 , and it increased to $2 \%$ in 2016, rising 0.2 points. The lowest income group of $20 \%$, which is the sum total of the first four 5 percentiles, receives $6.2 \%$ from the GDP. Annual approximate income of a person in the fourth 5 percentile is 7,788 TRY; monthly income per capita is 649 TRY. The daily income per capita is 21.6 TRY; $7.15 \$$. The monthly income of a family of four in this group is 2,596 TRY, and it equals to the salary of 2,564 TRY of a civil servant of 9/1 grade, in the same year.

The arithmetic mean of the third and fourth 5 percentiles gives us the poverty threshold, based on the $50 \%$ median income. This sum is per capita 7,245 TRY annually; 603.75 TRY monthly; and 20,12 TRY daily. It equals to $6.66 \$$ on the basis of dollars.

\subsection{Methods for Calculating the Zakat Potential in Turkey}

The first zakat potential studies in Turkey were conducted by the end of 1980s. There are three methods to calculate the zakat potential. These are the method to calculate the zakat potential based on the GDP, the method to calculate the zakat potential based on the Credit Suisse Global Wealth Report and the method to calculate the zakat potential based on the Forbes Richest 100 List.

\subsubsection{Calculating the Zakat Potential Based on the GDP}

In the calculation of zakat potential based on the GDP, zakat is calculated by the $5 \%$ or $\% 10$ of the components of agriculture and industry revenues, and $2.5 \%$ of the service revenues. Indirectly measured financial intermediation, tax and subsidies are excluded from zakat. In the agriculture sector, the zakat ratio to designate the zakat potential is $1 / 20$, as production is generally achieved by irrigation (El-Kardavi, 1973: 468; Tabakoğlu and Turan, 2017: 918). The zakat ratio of the industry sector is $5 \%$, and that of the service sector is $2.5 \%$. Özek et al. (1987), Zaim (1987), Kahf (1989) and Shirazi (2014) used this method to calculate the zakat potential.

\subsubsection{Zakat Potential Based on the Credit Suisse Global Wealth Report}

In the calculation of the zakat potential based on the Credit Suisse Global Wealth Report, the richest $10 \%$ of the population is taken into account. The population under 20 years of age is 
not taken into account. In the calculation of the zakat potential, $1 / 40(2.5 \%)$ of the total wealth of the richest $10 \%$ is designated as the zakat potential (Tabakoğlu and Turan, 2017: 903).

These assets are calculated, and the debts are deducted. In this calculation method acquired, it is aimed to make the best zakat estimations, based on the household balance sheet data. Although financial and nonfinancial data may not be precisely accurate in calculating the amount of wealth per capita, they are not far from the reality. (Tabakoğlu and Turan, 2017: 902).

\subsubsection{The Zakat Potential Based on the Forbes Magazine the Richest 100 List}

In this calculation method, the stocks, real estate values and all the other assets of the richest 100 are calculated, based on the list by the Forbes Magazine issued every year. It is stated that this method is more accurate than the other two methods in calculating the zakat potential, as in this method, the wealth of the 100 people is calculated by the experts. The real estate and other assets, along with the value of the stocks owned are taken into account. The unfavorable side of this method is that it is not known whether there are non-Muslims in the list, and that the assets included in the calculation cannot be known in detail (Tabakoğlu and Turan, 2017: 903).

\subsection{A Trial for Calculating the Zakat Potential in Turkey}

\subsubsection{Literature Review}

The studies on the zakat potential in Turkey began in the 1980s. A book prepared by Özek et al. (1987) and published by ISAV attempts to estimate the zakat potential in Turkey.

In the article titled "Zekatın İktisadi Önemi” (The Economic Importance of Zakat), Zaim (1987) attempts to estimate the zakat potential in Turkey for 1986.

In the article titled "Zakat: Unresolved Issues in the Contemporary Fiqh", Kahf (1989) attempts to designate the zakat potential of some Islamic countries, including Turkey.

In the article titled "Integrating zakat and waqf into the poverty reduction strategy of the IDB member countries", Shirazi (2014) attempts to estimate the zakat potential in the Islamic Development Bank member countries.

Tabakoğlu and Turan (2017), considering Kahf's and Kardavi's opinions, measure the zakat potential in Turkey, and designate the ratio of the zakat potential to the GDP. In their study, although the zakat potential has been calculated, its impact on poverty reduction is not clearly defined. To fulfill this gap in the literature, this study examines the Turkish economy in 20122017 in terms of the practices suggested by Kardavi, presenting it in three different methods.

\subsubsection{Calculating the Zakat Potential in Turkey, Based on the GDP Method}

In the zakat calculations based on the GDP, as the haram and illegitimate revenues are included, it cannot be said that zakat is fard for all of them. Since there is no way to differentiate 
these revenues that are not subject to zakat, this calculation method may not give properly accurate results (Tabakoğlu and Turan, 2017: 919).

In their study, Özek et al. (1987) calculate the zakat potential in Turkey in 1983-1985. They calculate the ratio of the zakat potential to the GDP for 1984 as $1.9 \%$.

In his study, Zaim (1987) calculates the ratio of the zakat potential to the GDP in Turkey in 1986 as $1.8 \%$.

Furthermore, in his study in 1989, Kahf calculates the zakat potential in some Islamic countries, based on the traditional figh and on Kardavi's opinion. According to his calculations, the ratio of the zakat potential to the GDP in Turkey is $1.9 \%$ based on the traditional fiqh; $4.9 \%$ based on Kardavi's opinion; and 7.5\% based on Kardavi's opinion regarding that the zakat of real estate should be calculated as $2.5 \%$.

According to the calculation by Tabakoğlu and Turan, based on this method, the mean zakat potential in Turkey between 2012 and 2017 is around 2.78\% of the GDP. (Tabakoğlu and Turan, 2017: 919). It is possible that the real zakat potential is below this amount. However, the informal economy is excluded from this potential calculation.

Table 5: Turkey's GDP with Current Prices Based on the Economic Activity Sectors (Million TRY)

\begin{tabular}{|l|l|l|l|l|l|l|}
\hline Sectors & $\mathbf{2 0 1 2}$ & $\mathbf{2 0 1 3}$ & $\mathbf{2 0 1 4}$ & $\mathbf{2 0 1 5}$ & $\mathbf{2 0 1 6}$ & $\mathbf{2 0 1 7}$ \\
\hline $\begin{array}{l}\text { Agriculture, } \\
\text { forestry and } \\
\text { fishery }\end{array}$ & 112,635 & 115,658 & 124,586 & 161,448 & 161,304 & 188,651 \\
\hline Industry & 273,789 & 299,799 & 341,782 & 461,963 & 511,806 & 640,580 \\
\hline Construction & 61,807 & 69,557 & 79,765 & 190,619 & 223,363 & 265,680 \\
\hline Services & 815,224 & 903,090 & $1,009,365$ & $1,246,696$ & $1,402,413$ & $1,655,362$ \\
\hline Sectors Total & $1,263,456$ & $1,388,104$ & $1,555,498$ & $2,060,726$ & $2,298,896$ & $2,750,273$ \\
\hline $\begin{array}{l}\text { Indirectly } \\
\text { Measured } \\
\text { Financial } \\
\text { Intermediation }\end{array}$ & 22,390 & 25,195 & 25,063 & - & - & - \\
\hline Tax-Subsidies & 175,750 & 204380 & 217,732 & 277,921 & 309,629 & 354,633 \\
\hline $\begin{array}{l}\text { GDP } \\
\text { Sar }\end{array}$ & $1,416,816$ & $1,567,289$ & $1,798,293$ & $2,338,647$ & $2,608,525$ & $3,104,906$ \\
\hline
\end{tabular}

Source: TOBB Economic Report, 2012: 55; TOBB Economic Report, 2015: 34; TOBB Economic Report, 2017: 32. 
Table 6: Calculating the Zakat Potential Based on Turkey's GDP (Million TRY)

\begin{tabular}{|l|l|l|l|l|l|l|}
\hline & Agriculture & Industry & \multicolumn{1}{|c|}{ Services } & $\begin{array}{c}\text { Sectors } \\
\text { Total }\end{array}$ & $\begin{array}{c}\text { Zakat } \\
\text { Potential }\end{array}$ & $\begin{array}{c}\text { The Ratio } \\
\text { of Zakat } \\
\text { Potential } \\
\text { to GDP } \\
(\%)\end{array}$ \\
\hline 2012 & $\begin{array}{l}112,635 / 20 \\
=5,631.75\end{array}$ & $\begin{array}{l}273,789 / 20 \\
=13,689.45\end{array}$ & $\begin{array}{l}815,224 / 40 \\
=20,380.6\end{array}$ & $1,201,648$ & $39,701.8$ & 2.80 \\
\hline 2013 & $\begin{array}{l}115,658 / 20 \\
=5,782.9\end{array}$ & $\begin{array}{l}299,739 / 20 \\
=14,990\end{array}$ & $\begin{array}{l}903,089 / 40= \\
22,772.2\end{array}$ & $1,318,486$ & $43,545.1$ & 2.78 \\
\hline 2014 & $\begin{array}{l}124,586 / 20 \\
=6,229.3\end{array}$ & $\begin{array}{l}341,782 / 20 \\
=17,089\end{array}$ & $\begin{array}{l}1,009,365 / 40 \\
=25,234.1\end{array}$ & $1,475,733$ & $48,552.4$ & 2.78 \\
\hline 2015 & $\begin{array}{l}148,287 / 20 \\
=7,414.35\end{array}$ & $\begin{array}{l}371,458 / 20 \\
=18,572.9\end{array}$ & $\begin{array}{l}1,120,756 / 40 \\
=28,018.9\end{array}$ & $1,640,501$ & $54,006.15$ & 2.76 \\
\hline 2016 & $\begin{array}{l}161,304 / 20 \\
=8,065.2\end{array}$ & $\begin{array}{l}511,805 / 20 \\
=25,590.2\end{array}$ & $\begin{array}{l}1,402,423 / 40 \\
=35,060.5\end{array}$ & $1,234,008$ & $76,781.2$ & 2.94 \\
\hline 2017 & $\begin{array}{l}188,650 / 20 \\
=9,432,5\end{array}$ & $\begin{array}{l}640,580 / 20 \\
=32,029\end{array}$ & $\begin{array}{l}1,655,362 / 40 \\
=41,383.8\end{array}$ & $1,517,897$ & $82,845.3$ & 2.67 \\
\hline
\end{tabular}

Source: TOBB, 2012: 55; TOBB, 2015: 34; TOBB, 2017: 32.

\subsubsection{Calculating the Zakat Potential, Based on the Credit Suisse Global Wealth Report}

In Table 7, Turkey's zakat potential in 2015 has been calculated based on the Credit Suisse Global Wealth Report. Based on this method, Turkey's zakat potential is 20,756 250 thousand $\$$, and this equals to $60,193,125$ thousand TRY, corresponding to $2.57 \%$ of the GDP.

Table 7: Turkey's Zakat Potential in 2015 Based on the Global Wealth Report

\begin{tabular}{|l|l|}
\hline Global Wealth Report Data for 2015 & \multicolumn{1}{|c|}{$\$$} \\
\hline Total Wealth Worldwide & $250,145,000,000,000$ \\
\hline Total Wealth in Turkey & $1,025,000,000,000$ \\
\hline Ratio of Turkey's Wealth to Total Wealth Worldwide & $0.40 \%$ \\
\hline Ratio of the Richest 10\% in Turkey to Total Wealth & $81 \%$ \\
\hline Total Wealth of the Richest 10\% in Turkey & $830,250,000,000$ \\
\hline $10 \%$ of the Population Holding the Highest Wealth & $5,308,300$ \\
\hline Per Capita Wealth of the \% 10 & 19,303 \\
\hline Zakat Potential of the 10\% & $20,756,250,000$ \\
\hline
\end{tabular}

Source: Tabakoğlu and Turan, 2017: 922. 


\subsubsection{The Zakat Potential in Turkey, Based on the Forbes Method}

Based on this method, the wealth of the richest 100 in Turkey in 2015 was 100.4 billion \$. The $1 / 40$ of this amount is the zakat potential, and it is 2,510 million $\$$, corresponding to 6,827 million TRY (Tabakoğlu and Turan, 2017: 923). This also shows the big zakat potential of the richest 100 people in Turkey. Considering 1,465 million $\$$ as the required amount to save the people from poverty in Turkey, even the zakat potential of the richest 100 people in Turkey is sufficient to save people from absolute poverty.

The zakat potential was 2,367 million \$ in 2016; 2,572 million \$ in 2017; and 3,035 million \$ in 2018. It is indicated that the zakat potential of the richest 100 people is close to the $1 / 10$ of the probable potential (Tabakoğlu and Turan, 2017: 924). The greatness of the zakat potential in Turkey becomes evident, considering that 10 times of the zakat potential of the richest 100 people is the zakat potential of a country.

Table 8: The Wealth and Zakat Potential of the Richest 100 Turkish People Based on the Forbes Magazine

\begin{tabular}{|l|l|l|l|}
\hline Year & Wealth (Million \$) & Zakat Amount (Million \$) & Zakat Amount (Million TRY) \\
\hline 2015 & 100,400 & 2,510 & 6,827 \\
\hline 2016 & 94,700 & 2,367 & 7,148 \\
\hline 2017 & 102,900 & 2,572 & 9,387 \\
\hline 2018 & 121,400 & 3,035 & 14,416 \\
\hline
\end{tabular}

Source: Forbes, 2016; Forbes, 2018.

When 2015 is taken as the basis, the zakat potential is calculated as 54 billion TRY based on the GDP, the first method; 56.4 billion TRY based on the Credit Suisse Global Wealth Report, the second method; and the zakat potential of the 100 people is calculated as 6.8 billion TRY based on the Forbes Magazine the Richest 100 List, the third method. When it is defined that the potential of the richest 100 based on the Forbes report equals to approximately 1/10 of the country potential, the sum is 68 billion TRY. The fact that the figures are close to one another provides the estimated zakat potential. As the first method provides the zakat potential based on production and the second method based on wealth, and as zakat is calculated based both on production and on wealth, the zakat potential in 2015 was $54+56.4=110.4$ billion TRY. Taking the Prophet (pbuh)'s order into account stating: "when you make an estimation regarding zakat of the crops, leave 1/3 to the owner"(Yavuz, 2018: 605; Erkal,2008: 193), the approximate zakat potential is calculated as 73.6 billion TRY. This amount is close to the calculation based on the Forbes report. The unrecorded economy and mattress savings have not been taken into account, while calculating this potential. When these are also taken into account, it is reasonable to think that the real zakat potential is much higher than the probable potential calculated. 
Table 9: The Annual Transfer Amount in 2016 to Save the Poor in Turkey from Poverty

\begin{tabular}{|l|l|l|l|l|l|}
\hline & $\begin{array}{l}\text { Poverty } \\
\text { Threshold }\end{array}$ & $\begin{array}{l}\text { Annual Per } \\
\text { Capita } \\
\text { Income }\end{array}$ & $\begin{array}{l}\text { Poverty } \\
\text { Deficit }\end{array}$ & $\begin{array}{l}\text { Number of } \\
\text { People per } \\
\text { Percentile }\end{array}$ & $\begin{array}{l}\text { Transfer } \\
\text { Amount } \\
\text { (Million TRY) }\end{array}$ \\
\hline $1^{\text {st } 5 \text { Percentile }}$ & 7,245 & 3,569 & 3,676 & $3,990,743$ & $14,670$. \\
\hline $2^{\text {nd } 5 \text { Percentile }}$ & 7,245 & 5,465 & 1,780 & $3,990,743$ & 7,103 \\
\hline $3^{\text {rd } 5 \text { Percentile }}$ & 7,245 & 6,702 & 543 & $3,990,743$ & 2,167 \\
\hline Total TRY & - & - & - & - & 23,940 \\
\hline Total \$ & & & \multicolumn{3}{|l}{} \\
\hline
\end{tabular}

Source: Prepared by the writers based on TurkStat poverty data.

Based on Table 9, the amount required in 2016 to save the poor from relative poverty was 23,940 million TRY; 7,922 million \$. The zakat potential of the same year based on the wealth of the richest 100 Turkish people designated by Forbes magazine is 7,148 million TRY. When the country potential is estimated as the 10 times of this amount, it equals to 71,480 million TRY, and it makes 23,670 million \$, excluding the mattress savings. It is forecasted that the amount will increase when the mattress savings are included. It is estimated that approximately $1 / 3$ of the zakat potential will be sufficient to save the people in Turkey from poverty

\section{Conclusion and Recommendations}

This study has examined the importance of zakat in reducing poverty. As known the poverty is one of the most significant social problems in societies. Considering Islamic history, it can be seen that zakat had an effect on reducing poverty and that in this context, poverty was at times reduced and at times removed. Acting on the statistical data, it is observed that poverty is substantially in question in Turkey. In Turkey, even though some practices such as transfer expenditures, social aids and so on are present in poverty reduction, they cannot effectively remove this problem. On the other hand, the zakat potential, which has a significant value, is not benefitted from in a planned manner. It can be seen that the zakat potential of Turkey is higher than the total poverty figure, taking into account the GDP method, Credit Suisse Global Wealth Report and the Forbes Wealth Report. According to Shirazi's study (2014) on the poverty and zakat potential in the Islamic countries, the required transfer of funds to save the people living with an income under $2 \$$ in Turkey in 2005 equals to $0.244 \%$ of the GDP. Therefore, it is possible to remove poverty by means of the zakat potential, considering that the zakat potential in Turkey in the mentioned year is $1.77 \%$ of its GDP, based on the traditional fiqh; and 3.78\% and $4.26 \%$ based on Kardavi's opinion. Bilen (2016), too, shares similar results in his study based on Shirazi's research. In light of these data, it can be pointed out that in Turkey, it is possible to reduce poverty and even remove it completely by means of the zakat revenues. The society and economy are devoid of this benefit, as the zakat potential, which is a significant instrument, is not used. 
Within this context, first of all the government should take into consideration that the zakat potential is an important means to reduce poverty. The government should allocate a fund to collect zakat and distribute it to the appropriate recipients via this fund. The principle of distributing zakat where it is collected should be followed. This practice will help the trust in the zakat fund to increase and to encourage giving zakat. Thus, zakat can be collected effectively and make a significant contribution in poverty reduction. 


\section{References}

Açıkgöz, Reşat, YUSUFOĞLU, Ö. Şükrü (2012), “Türkiye'de Yoksulluk Olgusu ve Toplumsal Yansımaları", İnsan ve Toplum Bilimleri Araştırmaları Dergisi, Cilt 1, Sayı 1.

Akar, Muhlis, ESER, Ercan(2012), Zekâtı Anlamak, Diyanet İşleri Başkanlığı (DİB) Yayınları, 2. Bask1, Ankara.

Aktan, Coşkun Can (2002), “Dünyada Ve Türkiye'de İnsani Yoksulluk”, Yoksullukla Mücadele Stratejileri, Hak-İş Konfederasyonu Yayınları, Ankara.

Apak, Adem (2017), “Emevi ve Abbasiler Döneminde Zekât Uygulamaları”, Tarihte ve Günümüzde Zekât Uygulamaları, İSAV, Ensar Neşriyat, İstanbul.

Arabacı, Rabihan Y. (2014), “Gelir Dağılımı ve Yoksulluk” Sosyal Politika, Editörler: TOKOL, Aysel, ALPER, Yusuf, Dora Basım Yayın, Bursa.

Arpacıŏlu Özge, YILDIRIM, Metin (2011), “ Dünyada ve Türkiye'de Yoksulluğun Analizi”, Niğde Üniversitesi İ̈BF Dergisi, Cilt 4, Sayı 2, Niğde.

Bilmen, Ömer Nasuhi, Büyük İslam İlmihali, Bilmen Yayınevi, İstanbul.

Bilen, Mahmut(2016), Küresel Servet Eşitsizliği: Piyasa veya Devlet Eksenli çözümde İslam Ekonomisinin Konumu, Türkiye İslam İktisadı Dergisi, Cilt 3, Sayı 1, Şubat 2016.

Boynukalın, Mehmet (2017), “Zekâtın Toplanması ve Dağıtımı İlk Kurumsal Tecrübeler (Hulefa-i Râşidîn Dönemi)", Tarihte ve Günümüzde Zekât Uygulamaları, İSAV, Ensar Neşriyat, İstanbul.

Bozan, Mahmut (2010), "Yoksulluk Algısına Farklı Bir Bakış", Uluslararası Yoksullukla Mücadele Stratejileri Sempozyumu: Deneyimler ve Yeni Fikirler Bildiriler Kitabı, SYDGM Yayınları, Cilt 1, İstanbul.

Çalışkan, Şadan (2010), "Türkiye'de Gelir Eşitsizliği ve Yoksulluk”, Sosyal Siyaset Konferansları, Sayı 59, 2010/2.

Çilingiroğlu, Nesrin (2009), “Türkiye İstatistik Kurumu’nun 2002-2009 Yılları Arası Yoksulluk Bulguları", Toplum Hekimliği Bülteni, Cilt 28, Sayı 3, Eylül-Aralık 2009.

DPT (2010), Binyıl Kalkınma Hedefleri Raporu, Ankara.

Dumlu, Emrullah (2010), “İslam’ın İlk Dönemlerindeki Uygulamalar Ekseninde Kamusal Bir Gelir Olarak Zekât”, Atatürk Üniversitesi İlahiyat Fakültesi Dergisi, Sayı 3, Erzurum.

El-Kardavi, Yusuf(2017), Ekonomik Sorunların Çözümünde Zekâtın Rolü, Nida Yayıncılık, 2. Bask1, İstanbul.

El-Kardavi, Yusuf(1973), F1khu'z-Zekat, Cilt 1, Beyrut.

Ensari, Sıddık (2010), “TurkStat'in Yoksulluk Analizleri Üzerine”, Maliye Finans Yazıları, Y11 24, Say1 87. 
Er, İzzet (2016), “Zekâtın Manevi ve Sosyo-Ekonomik Anlamı”, İstanbul Müftülügüü, Din ve Hayat Dergisi, Sayı 29, İstanbul.

Erkal, Mehmet(2008), Zekât Bilgi ve Uygulama, Marmara Üniversitesi İlahiyat Fakültesi Yayınları, 2. Baskı, İstanbul.

Erkal, Mehmet (2007), İlmihal 1 İman ve İbadetler, Türkiye Diyanet Vakfı Yayınları, Ankara.

Forbes, En Zengin 100 Türk, http://www.cnnturk.com, 29,02,2016.

Forbes (2018), En Zengin 100 Türk, Mart 2018.https://www.ntv.com.tr

Gönel, Feride Doğaner (2010), Kalkınma Ekonomisi, Efil Yayınevi, Ankara.

Gül, Songül Sallan (2002), “Türkiye'de Yoksulluk ve Yoksullukla Mücadelenin Sosyolojik Boyutları: Göreliden Mutlak Yoksulluğa", Yoksulluk, Şiddet ve İnsan Hakları, Türkiye ve Ortadoğu Amme İdaresi Enstitüsü (TODAİE) yayınları, Ankara.

Gül, Hüseyin, ERGUN, Cem (2003),"Mutlak Yoksulluk ve Nedenleri: Ankara Örneği” Yoksulluk Sempozyumu, Deniz Feneri Yayınları,İstanbul, birinci baskı.

Kabaş,Tolga (2010), Türkiye'de En Yoksul \% 20'nin Yoksulluk Profili, Gelir Dağılımı ve Tüketim Harcaması, Ç.Ü. Sosyal Bilimler Enstitüsü Dergisi, Cilt 19 Sayı 2

Kahf, Monzer(1989), Zakat: Unresolved Issues in the Contemporary Fiqh, Journal of Islamic Economics, Vol. 2, No. 1, January 1989.

Kayalıdere. Gül, ŞAHİN, Hande (2014), “Sosyal Devlet Anlayışı Çerçevesinde Türkiye'de Sosyal Koruma Harcamalarının Gelişimi ve Yoksulluk", Siyaset, Ekonomi ve Yönetim Araştırmaları Dergisi Yı1 2, Cilt 2, Sayı 2.

Kılıç, Ünal (2017), “Hz. Peygamber Döneminde Zekât Uygulaması”, Tarihte ve Günümüzde Zekât Uygulamaları, İSAV, Ensar Neşriyat, İstanbul.

Kızıler, Neslihan (2017), “Türkiye' de Yoksullukla Mücadele ve Sosyal Transfer Harcamaları”, Journal of Life Economic, dergipark.gov.tr

Kutup, Seyyid (1968), İslam'da Sosyal Adalet, Çevirenler: TUNAGÜR, Yaşar, MANSUR, M. Adnan, Cağaloğlu Yayınevi, İstanbul.

Özdemir, M. Çağlar (2017), “Gelir Eşitsizliği Ölçüm Yöntemleri”, Gelir Dağılımı ve Yoksulluk Kavram-Teori-Uygulama, Seçkin Yayıncılık, Ankara.

Özek, Ali, HAMITOĞULLARI, Beşir, SINAV, Tahsin, BAYRAKTAR, Mehmet, ADALI, Sacit, ENSARİ, Sıddık ve BULAÇ, Ali (1987), Türkiye'de Zekat Potansiyeli, İSAV, İstanbul.

Öztürk, Mustafa, ÇETİN, Başak Işıl, “Dünyada Ve Türkiye'de Yoksulluk Ve Kadınlar”, Journal of Yaşar University http://joy.yaşar.edu.tr.

Rizvi, S. Ameenul Hasan (1981), "Zakat: Its Place and Position in Islam”, The MWL Journal, Vol 8 (3), January 1981, Makkah 
Saad, Ram Al Jaffri, SAWANDİ, Norfaiezah, MOHAMMAD, Rayahu (2016), Zakat Surplus Funds Management, International Journal of Economics andFinancial Issues, Vol 6, Spesial Issues (S7).

Samad, Abdus, GLENN, Lowell M. (2010), “Development of Zakat Coverage in Monotheistic Faiths", International Journal of Social Economics, Vol 37, No 4, March 2010.

Shirazi, Nasım Shah(2014), Integrating Zakat and Waqf into the poverty reduction Strategy of the IDD Member Counries, Islamic Economic Studies, Vol. 22, No. 1, May 2014.

Tabakoğlu, Ahmet, TURAN, Melih (2017), "Türkiye'de Zekât Potansiyelinin Yeniden Tespiti”, Tarihte ve Günümüzde Zekât Uygulamaları, İSAV, Ensar Neşriyat, İstanbul.

Taş, H. Yunus, ÖZCAN, Selami (2012), “Türkiye'de ve Dünya'da Yoksulluk Üzerine Bir Araştırma", International Conference On Eurasian Economies, avekon.org/papers/544.pdf

Tatlı, Halim (2013), Yoksulluk Ve Sosyal Sermaye, TRB1 Bölgesinde (Malatya, Elazığ, Bingöl, Tunceli) Bir Araştırma, Doktora Tezi, Erzurum.

Tireli, Münir (2009), Küreselleşme ve Yoksulluk: Birleşmiş Milletler (UNDP) ve Dünya Bankası Göstergeleri Işığında Bir Analiz, Sosyal Yardım Uzmanlık Tezi, T.C. Başbakanlık Sosyal Yardımlaşma ve Dayanışma Genel Müdürlüğü, Ankara.

Republic of Turkey Ministry of Family and Social Policies (2016), https://www.csgb.gov.tr/media/1692/2016

TOBB Economic Report (2012), Türkiye Odalar ve Borsalar Birliği, Yayın No 2013/198, Özyurt Matbaacilık, Ankara.

TOBB Economic Report (2015), Türkiye Odalar ve Borsalar Birliği, Yayın No 2016/270, Gökçe Matbaacılık, Ankara.

TOBB Economic Report (2017), Türkiye Odalar ve Borsalar Birliği, Yayın No 2018/306, Özyurt Matbaacilık, Ankara.

TurkStat (2015), Poverty Study.

TurkStat (2017),

TÜSİAD (2000), Türkiye'de Bireysel Gelir dağılımı ve Yoksulluk, Avrupa Birliği ile Karşılaştırma, Aralık 2000, Yayın No. TÜSİAD-T/ 2000-12/295, İstanbul.

Yavuz, Yunus Vehbi(2018), İslâmda Zekât Müessesesi, 6. Baskı, Sebat Ofset, Konya.

Yavuz, Yunus Vehbi (1972), İslamda Zekât Müessesesi, Feyiz Yayınları, No 3, İstanbul

Yeşilyurt, Şahin (2015), “İmam Ebu Yusuf' un Kamu Maliyesi Alanına Katkısı”, Maliye Dergisi, Sayı 169, Temmuz-Aralık 2015.

Yıldırım, Celal (1980), Kaynaklarıyla İslam F1khı, 3. Baskı, Cilt 2, Uysal Kitabevi, Konya. 
Yıldırımalp, Sinem (2017), “Türkiye'de Yoksulluk Sorunu”, Gelir Dağılımı ve Yoksulluk Kavram - Teori - Uygulama, Editörler: ÖZDEMİ, M. Çağlar, İSLAMOĞLU, Emel, Seçkin Yayıncılık San. ve Tic. A.Ş., Ankara.

Zaim, Sabahattin(1987), “Zekatın İktisadi Önemi”, Türkiye'de Zekat Potansiyeli, İSAV, İstanbul. 